\title{
Media and Life Dissatisfaction as Predictors of Body Dissatisfaction
}

\author{
Melissa Bittencourt Jaeger ${ }^{1}$ \\ Universidade Federal de Ciências \\ da Saúde de Porto Alegre, \\ Porto Alegre-RS, Brazil
}

\author{
Sheila Gonçalves Câmara \\ Universidade Federal de Ciências \\ da Saúde de Porto Alegre, \\ Porto Alegre-RS, Brazil
}

\begin{abstract}
Body dissatisfaction can contribute to social, occupational and recreational losses, constituting a risk factor to health. This study aimed to evaluate the predictors of body dissatisfaction regarding demographic variables, media and life satisfaction among university students. The sample consisted of 321 participants older than 18 years. Body dissatisfaction, life dissatisfaction and media messages internalization were evaluated by Escala de Silhuetas para Adultos Brasileiros, Subjective Well-Being Scale and Sociocultural Attitudes Towards Appearance Questionnaire-3, respectively. Data were collected by an online survey tool (SurveyMonkey ${ }^{\mathbb{R}}$ ) and were analyzed using multiple linear regression. It was found that body dissatisfaction was positively related to inaccuracy in the perception of body size, Body Mass Index, life dissatisfaction, media messages internalization and television exposure. These findings evidence the importance of these predictors in the dynamics of body dissatisfaction, which support the development of preventive and treatment interventions.
\end{abstract}

Keywords: communications media, body image, satisfaction, subjective well-being scale

\section{Mídia e Insatisfação com a Vida Como Preditores de Insatisfação Corporal}

\begin{abstract}
Resumo: A insatisfação corporal pode contribuir para prejuízos sociais, ocupacionais e recreativos, constituindo-se em fator de risco à saúde. O objetivo deste estudo foi avaliar os preditores de insatisfação corporal em relação a variáveis demográficas, mídia e satisfação com a vida entre universitários. A amostra foi composta por 321 participantes com idade superior a 18 anos. A insatisfação corporal, satisfação com a vida e internalização de mensagens midiáticas foram avaliadas, respectivamente, pela Escala de Silhuetas para Adultos Brasileiros, Escala de Bem-Estar Subjetivo e Sociocultural Attitudes Towards Appearance Questionnaire-3. Os dados foram coletados pela ferramenta de pesquisa on-line SurveyMonkey ${ }^{\mathbb{B}}$ e analisados mediante regressão linear múltipla. Verificou-se que a insatisfação corporal está associada positivamente com inacurácia na percepção do tamanho corporal, Índice de Massa Corporal, insatisfação com a vida, internalização de mensagens midiáticas e exposição à televisão. Estes achados evidenciam a importância destes preditores na dinâmica da insatisfação corporal, o que pode favorecer o planejamento de intervenções preventivas e de tratamento.
\end{abstract}

Palavras-chave: meios de comunicação, imagem corporal, satisfação, escala de bem-estar subjetivo

\section{Medios de Comunicación y Satisfacción con la Vida Como Predictores de Insatisfacción Corporal}

\begin{abstract}
Resumen: La insatisfacción corporal puede contribuir para pérdidas sociales, ocupacionales y recreativas, constituyéndose en factor de riesgo para la salud. El objetivo de este estudio fue evaluar los predictores de insatisfacción corporal con relación a variables demográficas, media y satisfacción con la vida entre universitarios. La muestra se compuso por 321 participantes con edad superior a 18 años. La insatisfacción corporal, la satisfacción con la vida e internalización de mensajes mediáticas fueron evaluadas, respectivamente, por la Escala de Silhuetas para Adultos Brasileiros, Escala de Bem-Estar Subjetivo, e Sociocultural Attitudes Towards Appearance Questionnaire-3. Los datos fueron colectados por la herramienta de investigación online SurveyMonkey ${ }^{\mathbb{B}}$ y analizados mediante regresión linear múltiplo. Fue verificado que la insatisfacción corporal está asociada positivamente a inexactitud en la percepción del tamaño corporal, índice de masa corporal, insatisfacción con la vida, internalización de mensajes mediáticas y exposición a la televisión. Estos resultados evidencian la importancia de estos predictores en la dinámica de la insatisfacción corporal, lo que favorece la planificación de intervenciones preventivas y de tratamiento.
\end{abstract}

Palabras clave: medios de comunicación, imagen corporal, satisfacción, escala de bienestar subjetivo

The social communications media relate to the vehicles responsible for spreading information, such as radio, newspapers, magazines, television and the Internet. Of these, television is most widespread in Brazil, being present in $91.4 \%$ of residences in Brazilian territory (Conti, Bertolin,

\footnotetext{
1 Correspondence address:

Melissa Bittencourt Jaeger. Avenida Independência, 44, apto 1602. CEP 90035-070. Porto Alegre-RS, Brazil. E-mail: melissa_jaeger@hotmail.com
}

\& Peres, 2010). The social communications media have been increasingly present in the contemporary lifestyle of children, young people, adults and older adults. They spread values, standards, concepts and ideas which contribute to the formation of peoples' social representations and attitudes, there being no example in society which does not have a profound relation with the media (Furtado, 2009).

The media is understood as a complex of communications media involving messages and reception, and which has as 
an essential characteristic the manipulation of symbolic elements (Fonseca, 2011). Thus, the mass communications media have an important role in the social production of subjectivity, creating ways of perceiving, representing, reacting affectively and acting in the world, it being essential to take this relation into account when one studies the media (Conselho Federal de Psicologia, 2009).

Contemporary society has been permeated by these mass communications media, these being inseparable from cultural and social institutions. The media, at the same time, form part of the organization of society and culture, being an interdependent institution in relation to other institutions (Hjarvard, 2012). It can influence aesthetic values, norms and standards incorporated by society, and is able to transmit and reinforce social ideas related to the body. Reading magazines, exposure to pictures of slim bodies and watching television, for example, have an impact on body satisfaction, in particular among women (Alvarenga, Dunker, Philippi, \& Scagliusi, 2010; Halliwell, 2013).

In this study, concepts were adopted which are anchored in the socio-cultural perspective in relation to body image. This line of research is focused on investigating the extent to which social values influence individual values and the behaviors adopted by each one. It is based in social theories which assume that cultural values are important to the understanding of how subjects are perceived one by another and how the subjects themselves perceive themselves (Jackson, 2002). As a result, the sociocultural variables can be configured as considerable risk factors for body dissatisfaction. The subject may adopt behaviors due to these being appropriate to her network of values, through the internalization of an ideal body standard (Martins, 2013).

According to Cash and Smolak (2011), body satisfaction is considered a component of body image, it being the case that the latter must be understood as a multidimensional and complex phenomenon. Body image is a singular factor for each human being, as it reflects the life history and trajectory of identities, emotions, thoughts and representations. It is structured in a continuous exchange with other people, in interaction with the environment. It is, therefore, directly linked to external stimuli and affective experiences of the person's own body (Tavares, 2003). Another component of body image is inaccuracy in the perception of body size, which, according to Kakeshita and Almeida (2006) occurs through conditions of the sociocultural environment, with important roots in the mass communications media which privilege models of beauty similar to people with anorexia. Hence, cultural values are important in understanding how the subjects are perceived one by the other and how they perceive themselves (Tavares \& Campana, 2009).

At the time of writing, the communications media have explored the issue of the body, addressing the parameters of a society which reinforces an idealized physical appearance. The persistent search for this body standard seems to be related to the personal fulfillment, and, possibly, satisfaction with life, this association being one of the main aspects implicated in the alterations in perception of body image (Tod, Edwards, \& Hall, 2013).

The sensation of well-being or of satisfaction with life is closely linked with how the individual is capable of dealing with and absorbing the occurrence of episodes in her life. A break in the sensation of feeling psychologically well may be associated with poor management of stressful events in the personal, social or cultural spheres, which affects behaviors and influences the subject's perception of health, bringing personal suffering (Silva et al., 2007).

In the study by Campana, Ferreira and Tavares (2012), undertaken with adults, it was observed that internalization of media messages regarding information on beauty was related to the acceptance of aesthetic plastic surgery, it being the case that, among women, this acceptance was associated with dissatisfaction with life. However, in order to verify dissatisfaction with life, only one question referent to this issue was used. In spite of these results, Brazilian studies with adults, which relate body dissatisfaction to dissatisfaction with life and the internalization of media messages have not yet been published with this approach.

Generally speaking, dissatisfaction with one's own body can contribute to increasing disorders associated with aesthetics, such as anorexia, bulimia, vigorexia (considering oneself to be small and weak, in spite of major muscular hypertrophy) and a mania for plastic surgery (compulsive practice for plastic surgery, insisting on recurrent surgical interventions purely for aesthetic ends). In addition to this, body dissatisfaction may contribute to social, occupational and recreational harm, constituting a risk factor to health (Furtado, 2009). Based on this panorama, and given the scarcity of investigations in this field, the present study aimed to evaluate the predictors for body dissatisfaction in relation to demographic, media and satisfaction with life variables among university students.

\section{Method}

\section{Participants}

This is an observational, analytical and transversal study, whose participants were students from the area of health (biomedicine, nursing, pharmacy, physiotherapy, speech therapy, gastronomy, medicine, nutrition, psychology and analytical toxicology) from a public university in the State of Rio Grande do Sul, aged between 18 and 57 years old. For calculating the sample, the researchers considered the total number of students enrolled in 2013 (1545), and expected prevalence for the outcome of $50 \%$, a maximum tolerated error of $\pm 5 \%$ and a confidence level of $95 \%$. As a result of this, the sample was calculated at 308 students. A possible design effect of 1.2 was considered and $15 \%$ were added in order to compensate for the losses. In this way, the sample size was calculated at 416 university students. In total, 424 university students accepted to participate in the 
study, however, those who did not respond to at least $90 \%$ of the questionnaire were considered as losses (24\%). Thus, the final sample was made up of 321 participants. The inclusion criteria were: to be a student of the university studied, and to be aged 18 years old or over. Minors and pregnant students were excluded.

\section{Instruments}

Demographic questionnaire. Information was collected such as sex (male and female), race/color (white, black, mixed black and white, oriental 'Asian origin' and indigenous), sexual orientation/gender identity (heterosexual, homosexual, bisexual, transvestite, transsexual and transgender), marital situation (with companion and without companion), religious belief (with and without belief) and the Brazilian Criteria for Economic Classification, made up of 10 questions, containing possession of certain items and the educational level of the head of the family (A1, A2, B1, B2, C1, C2, D and E) (Associação Brasileira de Empresas de Pesquisa, 2013).

Self-Reported Body Mass Index (BMI). The participants were requested to state their weight and height (information referent to the last time that they weighed and measured themselves). According to the study by Peixoto, Benicio and Jardim (2006), undertaken with 1,023 participants aged between 20 and 64 years old, the self-reported measurements can be used in substitution for checked measurements in both sexes and all age ranges, as these present a high degree of concordance. Nutritional status was classified in accordance with the BMI categories of the World Health Organization (World Health Organization, 2013) and analyzed as: underweight $\left(\mathrm{BMI} \leq 18.49 \mathrm{~kg} / \mathrm{m}^{2}\right)$, normal range $\left(\mathrm{BMI}=18.50-24.99 \mathrm{~kg} / \mathrm{m}^{2}\right)$ and overweight/obesity (BMI $\geq 25 \mathrm{~kg} / \mathrm{m}^{2}$ ).

Escala de Silhuetas para Adultos Brasileiros (The Silhouette Scale for Adult Brazilians) (Kakeshita, Silva, Zanatta, \& Almeida, 2009). This scale evaluates body dissatisfaction in men and women, considering it to be the difference between the BMI of the silhouette indicated as the desired body and the BMI of the silhouette indicated as the actual body. Furthermore, it allows the evaluation of the inaccuracy in the perception of body size, by the difference between the actual BMI (self-reported weight/height ${ }^{2}$ ) and the BMI of the silhouette indicated as actual. In this regard, there is always some inaccuracy (overestimation or underestimation). The scale is made up by 15 silhouettes, which vary from very thin to very fat, with each one of the extremities related to the mean BMI of 12.5 to $47.5 \mathrm{~kg} / \mathrm{m}^{2}$, with an interval of $2.5 \mathrm{~kg} / \mathrm{m}^{2}$ between each figure. According to the instrument's authors, the scale presents good correlation between the BMI of the subject and of the silhouette indicated as representative of the actual body $(r=.93)$. On the women's scale, the coefficients of reliability varied between .66 and .93 and in the male, between .53 and .93 . In order to evaluate body dissatisfaction, the interviewee must select the figure closest to his/her body and the figure closest to the body he/she wishes that he/she had. The discrepancy between the actual figure and that wished for serves as a measurement of body dissatisfaction, with greater discrepancy representing greater dissatisfaction with the body. The use of the scale for virtual application was authorized, by email, by the authors.

Questionnaire for Media Consumption Habits. Formulated by the researchers specifically for this study, in order to identify the frequency of accessing communications media (Internet, television, newspapers and magazines) and the amount of time spent exposed to the same ( 0 to 7 days per week) and ( 0 to 6 hours or more per day) based on self reporting and on subjective perception.

Sociocultural Attitudes Towards Appearance Questionnaire-3 (SATAQ-3) (Thompson, van den Berg, Roehrig, Guarda, \& Heinberg, 2004). This contains 30 items aiming to evaluate the internalization of media messages, divided in four factors: Factor 1 - general internalization, which focuses on information related to beauty and attractiveness, vehicled by the various media channels; Factor 2 - athletic internalization which represents the influence of the athletic body on the evaluation and investment in appearance; Factor 3 - pressure, which reflects the parameters of the perfect body and the extent to which the media influences the subject to pursue this; and Factor 4 - information, relating to the extent to which the media channels are considered important as a source of information regarding being attractive. The result of the scores is given by the sum of the answers in each factor. The higher the score, the greater is the internalization of the media messages specific to the factor. In the validation for the Portuguese language in Brazil (Amaral, 2011), the scale presented satisfactory Cronbach alpha coefficients $(\alpha>.65)$.

Subjective Well-Being Scale (EBES). Developed by Albuquerque and Troccoli (2004), this is made up of two subscales. The first (47 items) evaluates positive and negative feelings, and the second (15 items) evaluates satisfaction with life. In the present study, only the second subscale was used, of satisfaction with life (SL), made up of 15 items (satisfaction with life, I take advantage of life opportunities, I evaluate life positively, life is far from the ideal, I would change the past if I could, I have achieved what I expected of life, life is as wished for, I like life, life is bad, dissatisfied with life, life could be better, there is more sadness than happiness, life is no fun, living conditions are good, I consider myself happy). The items are responded to using a five-point Likert scale - 1 (completely disagree) to 5 (completely agree). The coefficients for internal consistency found by the scale's authors varied from .90 to .95 in an adult nonclinical population.

\section{Procedure}

Data collection. Data collection was undertaken in the period May-August 2013. The university students 
were invited to participate in the study through virtual contact via email and by publicity in social networks, and through contacts or groups related to the target-public. The self-administered instruments were made available in the SurveyMonkey ${ }^{\circledR}$ virtual environment (online research tool), which allows the exporting of data collected to the statistical package format. The mean time for answering the online questionnaire was 15 minutes.

Data analysis. The data were analyzed using the Statistical Package for the Social Sciences ${ }^{\circledR}$ (SPSS) software, version 17.0. Descriptive statistical analyses were used for presentation of the sample, and multivariate analysis (analysis of multiple regression, using the stepwise method) was used for evaluating the predictor variables for body dissatisfaction.

In order to evaluate the relation of demographic variables, internalization of media, and satisfaction with life with body dissatisfaction, a simple regression was firstly made with all the independent variables. Based on that, those variables which presented $p \leq .20$ were identified in order to be considered in the multiple regression. The identified variables were: sex, age, inaccuracy in perception of body size, normal range BMI and overweight/obesity, normal range $\mathrm{BMI}$ and underweight, factors 1,3 and 4 of the SATAQ-3, frequency of access to the Internet and television, daily hours spent accessing the Internet and television, and the 15 items of the satisfaction with life scale.

In relation to the predictors for body dissatisfaction, three different models of multiple linear regression were tested, based on distinct hypotheses regarding the BMI variables and inaccuracy in perceiving body size regarding the dependent variable. In all the models, dissatisfaction with body image was considered a dependent variable, and the following were considered as independent variables: sex, age, factors 1, 3 and 4 of the SATAQ-3, frequency of access to the Internet and television, daily hours spent accessing the Internet and television, and the 15 items of the satisfaction with life scale.

In the first model, the BMI variables and inaccuracy in the perception of body size were not inserted in the regression, as the researchers considered the possibility of these variables explaining most of the variance in body dissatisfaction. In model two, the variables of inaccuracy in perception of body size and BMI were inserted, this last being considered in terms of the normal range and overweight/obesity. In the third and last model, the variables of inaccuracy in perception of body size and BMI were inserted, considering underweight and normal range. For the analysis of the results, a confidence interval of $95 \%$ was adopted.

\section{Ethical Considerations}

This study was started following the approval of the research project by the Research Ethics Committee of the Universidade Federal de Ciências da Saúde de Porto Alegre (Opinion no. 279.391 / CAAE: 15972513.6.0000.5345).

\section{Results}

The sample's mean age was 23.3 years old $(S D=5.81)$, with 256 students $(79.8 \%)$ being female. In relation to marital situation, practically half of university students $(50.8 \%)$ reported having a partner at that time. The majority $(92.5 \%)$ stated that they were white and $64.5 \%$ mentioned having some form of religious belief. In relation to sexual orientation, $87.5 \%$ considered themselves to be heterosexual, $6.9 \%$ bisexual, $4.4 \%$ homosexual, and $1.2 \%$ other. According to the Brazilian Criteria for Economic Classification, 59.3\% of the participants belonged to class $\mathrm{B}, 21.8 \%$ to $\mathrm{A}$ and $19.9 \%$ to classes $\mathrm{C}$ and $\mathrm{D}$.

The mean BMI was $23.17 \mathrm{~kg} / \mathrm{m}^{2}(S D=3.91)$, with the majority $(70.1 \%)$ presenting normal range $\left(\mathrm{BMI}=18.50-24.99 \mathrm{~kg} / \mathrm{m}^{2}\right)$. On the other hand, $24.6 \%$ of university students were overweight/obese $\left(\mathrm{BMI} \geq 25 \mathrm{~kg} / \mathrm{m}^{2}\right)$ and $5.3 \%$ had underweight $\left(\mathrm{BMI} \leq 18.49 \mathrm{~kg} / \mathrm{m}^{2}\right)$. In spite of this, $79.1 \%$ of the university students were evaluated as dissatisfied according to the Silhouette Scale for Adult Brazilians. Of those who were dissatisfied, $81.1 \%$ presented the wish to reduce body size, while $18.9 \%$ mentioned wanting to increase body size. In addition to this, it was ascertained that the mean for dissatisfaction among women $(M=4.86 ; S D=4.09)$ was significantly superior to that of men $(M=3.57 ; S D=2.93)$, according to the results of the Student t-test $(t=2.38 ; p=.02)$. In relation to the inaccuracy in the perception of body size, the results indicated that $81.3 \%$ of the participants overestimated their body, and $18.7 \%$ underestimated it.

In relation to the Media Consumption Habits, the communications media accessed most was the Internet, with a mean frequency of access of seven times per week, from 2 to 4 hours per day. For television, the mean for access was four times per week, from 1 to 2 hours per day. The mean for accessing newspapers was once per week, while magazines were the least accessed, with frequency of access below once per week.

In relation to the means of the scores of the SATAQ-3, it was ascertained that factor 1 presented the highest mean $(M=26.33 ; S D=8.33)$, followed by factor $4(M=25.91$; $S D=7.62)$, factor $3(M=21.86 ; S D=7.43)$ and factor 2 $(M=14.31 ; S D=3.57)$. In terms of satisfaction with life, the descriptive data by item of the EBES subscale for Satisfaction with Life are presented in Table 1.

Based on the multivariate analyses, three models predicting body dissatisfaction were obtained, in accordance with the independent variables considered. The first model, which did not include the variables of BMI and inaccuracy in perception of body size, obtained as predictors the item 'my life is bad' (SL), factor 3 (SATAQ-3) and daily hours spent accessing television, and explained $17 \%$ of the variance. Hence, the university students who are most dissatisfied with their bodies present a greater perception that their life is bad, suffer greater pressure from the media regarding the parameters of the perfect body, and spend more hours per day watching television, it being the case that considering one's life to be bad explains $10 \%$ of the 
variance (Table 2). This model made it possible to identify that, independent of body size and inaccuracy in perception of body size, considering one's life to be bad, watching more hours per day of television and suffering greater pressure from the media in relation to standards of the perfect body are associated with body dissatisfaction in this sample.

In model two, inserting the variables of inaccuracy in perception of body size and BMI (normal and overweight/obesity), the explanatory power increased to $55 \%$, and excluded the predictor 'daily hours accessing television' of the model. This model had, as predicted variables, inaccuracy in perception of body size, BMI (normal and overweight/obesity), factor 1 (SATAQ-3) and the item 'my life is bad' (SL). In this regard, the university students who are most dissatisfied with their bodies present greater inaccuracy in the perception of body size, have nutritional status of overweight/obesity, internalize more information from the channels of the media which focus on information related to beauty and attractiveness and have a greater perception that their life is bad (Table 3). It is important to indicate that, in

Table 1

Means and Standard Deviation of the Items of the Satisfaction With Life Subscale

\begin{tabular}{lcc}
\hline Satisfaction with life & $M^{*}$ & $S D$ \\
\hline I am satisfied with my life & 3.72 & 0.99 \\
I have taken advantage of life's opportunities & 3.91 & 0.90 \\
I evaluate my life positively & 3.88 & 0.95 \\
In nearly all aspects, my life is far from my ideal of life & 2.18 & 1.05 \\
I would change my past if I could & 2.80 & 1.27 \\
I have achieved everything I expected of life & 3.28 & 1.07 \\
My life is in accordance with what I wish for & 3.45 & 1.03 \\
myself & & \\
I like my life & 4.09 & 0.87 \\
My life is bad & 1.72 & 0.93 \\
I am dissatisfied with my life & 1.99 & 1.16 \\
My life could be better & 3.69 & 0.99 \\
I have more moments of sadness than happiness in & 1.87 & 1.05 \\
my life & & \\
My life is "no fun" & 2.09 & 1.14 \\
My living conditions are very good & 3.85 & 0.90 \\
I consider myself a happy person & 4.06 & 0.92 \\
\hline
\end{tabular}

Note. Negative items were inserted for the simple and multiple linear regression analyses.

$*$ Minimum value $=1$ and maximum value $=5$. spite of the variables of inaccuracy in perception of body size and BMI entering the model as predictors, the other variables (considering one's life to be bad and internalization of the media) were maintained.

In model three, when the variable of BMI (normal and overweight/obesity) was substituted by BMI (normal and underweight), similar variables entered, and the explanatory power was $44 \%$. As its predictor variables, this model had inaccuracy in the perception of body size, factor 1 (SATAQ-3), the item 'I evaluate my life positively' (SL) and daily hours accessing television. In this case, the university students who are most dissatisfied with their bodies present a greater inaccuracy in the perception of body size, internalize more information from channels of the media which focus on information related to beauty and attractiveness, evaluate life more negatively, and spend more hours per day watching television (Table 4). Distorting the body, internalizing information from the beauty and attractiveness media, evaluating life negatively and spending more hours per day watching television were related to body dissatisfaction. In this model, the variable of BMI (normal and underweight) did not enter as a predictor, indicating that this variable does not explain body dissatisfaction.

\section{Discussion}

This study evaluated the predictors of body dissatisfaction in relation to demographic variables, media, and satisfaction with life among university students. It was ascertained that, although the majority $(70.1 \%)$ of the participants present normal nutritional status, the prevalence of body dissatisfaction was high (79.1\%). Of this total of dissatisfied participants, the majority $(81.10 \%)$ wanted to reduce body size. The prevalence identified of dissatisfaction was similar, although greater, than that in the study by Miranda, Filgueiras, Neves, Teixeira and Ferreira (2012), who found a level of $76.6 \%$ of body dissatisfaction among university students. It is understandable that, in a culture that values thinness, it is sought to achieve this ideal of beauty, through wishing to reduce body size. Indeed, in the West, the concept of beauty is associated with youth and a thin body. Thus, meeting these standards can signify having competence, success and being sexually attractive. As a result, this concept of beauty ends by contributing to the increase of prevalence of body dissatisfaction (Alves, Pinto, Alves, Mota, \& Leirós, 2009; Tod et al., 2013).

Table 2

Model 1 of Variables Predicting Body Dissatisfaction, Excluding the Variables of BMI and Inaccuracy in Perception of Body Size

\begin{tabular}{lccccccc}
\hline \multirow{2}{*}{ Independent variables } & \multicolumn{7}{c}{ Body dissatisfaction } \\
\cline { 2 - 8 } & $R$ & $R^{2}$ & $\beta$ & Beta & $t$ & $p$ & CI (95\%) \\
\hline SL - My life is bad & .311 & .097 & 0.993 & .246 & 4.401 & .000 & $(-1.43--0.55)$ \\
SATAQ-3 - F3 & .380 & .144 & 0.114 & .233 & 4.172 & .000 & $(0.06-0.17)$ \\
Daily hours of television & .409 & .167 & 0.551 & .151 & 2.798 & .005 & $(0.16-0.94)$ \\
\hline
\end{tabular}

Note. SL = Satisfaction with Life Scale. SATAQ-3 = Sociocultural Attitudes Towards Appearance Questionnaire-3. 
Table 3

Model 2 of Variables Predicting Body Dissatisfaction, Including the Variables of BMI (Normal and Overweight/Obesity) and Inaccuracy in Perception of Body Size

\begin{tabular}{lccccccc}
\hline \multirow{2}{*}{ Independent variables } & \multicolumn{7}{c}{ Body dissatisfaction } \\
\cline { 2 - 8 } & $R$ & $R^{2}$ & $\beta$ & Beta & $t$ & $p$ & CI (95\%) \\
\hline Inaccuracy & .608 & .370 & 0.594 & 0.517 & 12.598 & .000 & $(0.48-0.67)$ \\
BMI (normal and overweight/obesity) & .725 & .525 & 2.888 & 0.384 & 9.450 & .000 & $(2.14-3.57)$ \\
SATAQ-3 - F1 & .747 & .558 & 0.068 & 0.150 & 3.548 & .001 & $(0.03-0.10)$ \\
SL-My life is bad & .759 & .576 & 0.592 & 0.144 & 3.418 & .001 & $(0.07-0.67)$ \\
\hline
\end{tabular}

Note. SL = Satisfaction with Life Scale. SATAQ-3 = Sociocultural Attitudes Towards Appearance Questionnaire-3.

Table 4

Model 3 of Predictive Variables for Body Dissatisfaction, Including the Variables of BMI (Normal and Underweight) and Inaccuracy in Perception of Body Size

\begin{tabular}{lccccccc}
\hline \multirow{2}{*}{ Independent variables } & \multicolumn{7}{c}{ Body Dissatisfaction } \\
\cline { 2 - 8 } & $R$ & $R^{2}$ & $\beta$ & Beta & $t$ & $p$ & CI (95\%) \\
\hline Inaccuracy & .618 & .382 & 0.596 & 0.581 & 11.318 & .000 & $(0.49-0.70)$ \\
SATAQ-3 - F1 & .644 & .415 & 0.055 & 0.141 & 2.636 & .009 & $(0.01-0.09)$ \\
SL - I evaluate my life positively & .657 & .432 & -0.452 & -0.131 & -2.475 & .014 & $(-0.81--0.09)$ \\
Daily hours of television & .665 & .442 & 0.353 & 0.104 & 2.045 & .042 & $(0.01-0.69)$ \\
\hline
\end{tabular}

Note. SL = Satisfaction with Life Scale. SATAQ-3 = Sociocultural Attitudes Towards Appearance Questionnaire-3.

Regarding inaccuracy in the perception of body size, the majority $(81.3 \%)$ overestimated body size, that is, they perceived themselves to be bigger than they were, it being the case that $70.1 \%$ of the sample presented normal weight. Such findings are similar to the study undertaken by Kakeshita and Almeida (2006), in which the majority of the women who were normal or overweight $(87 \%)$ overestimated their body size. According to Alvarenga, Philippi, Loureço, Sato and Scagliusi (2010), inaccuracy in perception of body size and body dissatisfaction can occur even taking into account nutritional status, that is, even people who fall within normal limits overestimate their body size.

Comparing the means for body dissatisfaction between the sexes, it was possible to ascertain a significant difference, with higher means among the women, corroborating the studies by Miranda et al. (2012), which pointed to significantly lower body dissatisfaction among men. According to these findings, men appear to be more healthy in relation to their body image, indicating that women still have exacerbated concern with body aesthetics in order to meet the socially established standard of beauty (Souza, Oliveira, Nascimento, \& Carvalho, 2013). Nowadays, and in Western culture, the concept of beauty is associated with youth, and a slim and attractive body for women; and with a larger and muscular body for men (Alves et al., 2009). In this regard, the standard of beauty, indicated preferentially by the media, affects both sexes, being related to the feeling of well-being and, therefore, to satisfaction with life. In spite of this, the variable of sex did not enter into any of the models as a predictor for body dissatisfaction.

In relation to multivariate analysis, comparing all the models, it was possible to observe that perceiving life negatively was related to body dissatisfaction in all the cases. Hence, in this sample, considering life to be bad and evaluating it negatively was related significantly to body dissatisfaction. In addition to this, in all the models, internalizing media messages regarding beauty and attractiveness, and feeling pressured by the media by standards of the perfect body was associated with body dissatisfaction, while watching more hours per day of television significantly related to body dissatisfaction in two of the models. These results quantitatively reinforce the study of Frois, Moreira and Stengel (2011), which noted that the means of mass communication, mainly television, have influenced the dissemination and valuing of a body standard, performing a broad role in increasing the search for an ideal, molded body, and contributing to dissatisfaction with life.

The social standards currently in place regarding feminine beauty emphasize the search for a thinness which is impossible for the majority of women to achieve by healthy means. In any fashion magazine, one can ascertain the preponderance of young bodies, of tall women, with long legs, who are extremely thin. In relation to the men, the media also exposes a form of the ideal body: young, thin, muscular bodies, with broad shoulders, flat stomachs and narrow hips (Tiggemann, 2002). The media broadly fails to consider the body diversity presented by the population, while obesity becomes an object of fear and even of rejection, sometimes being associated by the public with lack of care and of success (Furtado, 2009).

This exposure provided by the media is one of the main factors contributing to the current high levels of body dissatisfaction and eating disorders. According to Campana et al. (2012), these concerns with body image can cause 
social, occupational and recreational harm, as well as harm in other areas of the individual's functioning, thus constituting a risk factor for health. Hence, to the extent that the media presents specified types of bodies, it can drastically affect people's quality of life and increase dissatisfaction with the same. Dissatisfaction with life and with one's body can cause many people to subject themselves to aesthetic surgical interventions, identifying changes in the body as a means of achieving supposed satisfaction with life (Furtado, 2009).

This study demonstrated a relation between body dissatisfaction, BMI, inaccuracy in perception of body size, influence of the media, and dissatisfaction with life, among adult university students. It was also possible to verify that there is much inaccuracy and dissatisfaction relating to the body among young adults, and to quantitatively evidence the important role of the media in this process, regardless of the person's nutritional status. The innovation of the findings lies in the significant relation of the variables of dissatisfaction with life, as also being important predictors for body dissatisfaction in this sample. In this regard, it is possible to assert that the predictors found extrapolate the variables related to body image and media, also revealing that body dissatisfaction brings suffering in relation to life in general.

The knowledge of the variables which are associated with body dissatisfaction is necessary, as it provides support for planning future prevention and intervention strategies with adults. It is important to question the role of the media in relation to body dissatisfaction and dissatisfaction with life, in order to be able to think about interventions such that adults may develop a critical sense regarding media consumption, analyzing the content available. Hence, it is suggested that future studies should investigate the efficacy of possible interventions such as, for example, the method of media literacy, used in other countries, which has been shown to be efficacious in reducing body dissatisfaction among women with eating disorders (Coughlin \& Kalodner, 2006). This method makes it possible to make the person able to broaden their understanding regarding media communication, critically analyzing and reflecting upon the content exposed (Zanchetta, 2009).

Some limitations of this study relate to the scarcity of bibliography encompassing the relation found of dissatisfaction with life; to the process of data collection which, due to being virtual, did not allow the controlling of some variables, such as, for example, distribution by sex. However, it is understood that the greater number of female participants may be owed, precisely, to their interest in the subject under study. It is noteworthy that the loss of participants was $9 \%$, above that expected. This may compromise the representativeness of the population studied, however, the exclusion of participants who did not fill out $90 \%$ of the instrument was a choice which privileged the quality of the data for analysis. Furthermore, caution is suggested regarding the population studied, which corresponds to students of higher education, who may differ from adults with other educational levels. In relation to the instruments used, it is important to consider that the EBES tool was validated in a population of police officers, of whom $74 \%$ were male, differing significantly from the population studied here. However, guidance was followed from the scale's authors, who recommend it for the evaluation of subjective well-being in populations which do not deviate from normality in terms of mental health (Albuquerque \& Troccoli, 2004).

\section{References}

Associação Brasileira de Empresas de Pesquisa. (2013). Critérios de Classificação Econômica Brasil. Retrieved from http://www.abep.org/criterioBrasil.aspx

Albuquerque, A. S., \& Troccoli, B. T. (2004). Desenvolvimento de uma escala de bem-estar subjetivo. Psicologia: Teoria e Pesquisa, 20(2), 153-164. doi:10.1590/S0102-37722004000200008

Alvarenga, M. S., Dunker, K. L. L., Philippi, S. T., \& Scagliusi, F. B. (2010). Influência da mídia em universitárias brasileiras de diferentes regiões. Jornal Brasileiro de Psiquiatria, 59(2), 111-118. doi:10.1590/S0047-20852010000200006

Alvarenga, M. S., Philippi, S. T., Lourenço, B. H., Sato, P. M., \& Scagliusi, F. B. (2010). Insatisfação com a imagem corporal em universitárias brasileiras. Jornal Brasileiro de Psiquiatria, 59(1), 44-51. doi:10.1590/S0047-20852010000100007

Alves, D., Pinto, M., Alves, S., Mota, A., \& Leirós, V. (2009). Cultura e imagem corporal. Motricidade, 5(1), 1-20. doi:10.6063/motricidade.5(1). 184

Amaral, A. C. S. (2011). Adaptação transcultural e validação do Sociocultural Attitudes Towards Appearance Questionnaire - 3 (SATAQ-3) para população brasileira (Master's thesis). Retrieved from http://www.ufjf.br/ labesc/files/2010/06/DISSERTA $\%$ C3\%87\%C3\%83O_ FINAL_20.09.pdf

Campana, A. N. N. B., Ferreira, L., \& Tavares, M. C. G. C. F. (2012). Associações e diferenças entre homens e mulheres na aceitação de cirurgia plástica estética no Brasil. Revista Brasileira de Cirurgia Plástica, 27(1), 108-114. doi:10.1590/S1983-51752012000100018

Cash, T. F., \& Smolak, L. (2011). Understanding body images: Historical and contemporary perspectives. In T. F. Cash \& L. Smolak (Eds.), Body image: A handbook of science, practice, and prevention (2nd ed., pp. 3-11). New York, NY: Guilford.

Conselho Federal de Psicologia. (2009). Mídia e psicologia: Produção de subjetividade e coletividade (2nd ed.). Brasília, DF: Conselho Federal de Psicologia.

Conti, M. A., Bertolin, M. N. T., \& Peres, S. V. (2010). A mídia e o corpo: O que o jovem tem a dizer? Ciência \& Saúde Coletiva, 15(4), 2095-2103. doi:10.1590/S1413-81232010000400023 
Coughlin, J. W., \& Kalodner, C. (2006). Media literacy as a prevention intervention for college women at low- or high-risk for eating disorders. Body Image, 3(1), 35-43. doi:10.1016/j.bodyim.2006.01.001

Fonseca, F. (2011). Mídia, poder e democracia: Teoria e práxis dos meios de comunicação. Revista Brasileira de Ciência Política, (6), 41-69. doi:10.1590/S0103-33522011000200003

Frois, E., Moreira, J., \& Stengel, M. (2011). Mídias e a imagem corporal na adolescência: $O$ corpo em discussão. Psicologia em Estudo, 16(1), 71-77. doi:10.1590/S1413-73722011000100009

Furtado, E. R. G. (2009). Representações sociais do corpo, mídia e atitudes (Doctoral dissertation). Retrieved from http://repositorio.ufsc.br/bitstream/handle/123456789/ 92473/272199.pdf?sequence $=1 \&$ is Allowed $=y$

Halliwell, E. (2013). The impact of thin idealized media images on body satisfaction: Does body appreciation protect women from negative effects? Body Image, 10(4), 509-514. doi:10.1016/j.bodyim.2013.07.004

Hjarvard, S. (2012). Midiatização: Teorizando a mídia como agente de mudança social e cultura. Matrizes, 5(2), 53-91.

Jackson, L. A. (2002). Physical attractiveness: A sociocultural perspective. In T. F. Cash \& T. Pruzinsky (Eds.), Body image: A handbook of theory, research, and clinical practice (pp. 13-21). New York, NY: Guilford.

Kakeshita, I. S., \& Almeida, S. S. (2006). Relação entre índice de massa corporal e a percepção da auto-imagem em universitários. Revista de Saúde Pública, 40(3), 497-504. doi:10.1590/S0034-89102006000300019

Kakeshita, I. S., Silva, A. I. P., Zanatta, D. P., \& Almeida, S. S. (2009). Construção e fidedignidade teste-reteste de escalas de silhuetas brasileiras para adultos e crianças. Psicologia: Teoria e Pesquisa, 25(2), 263-270. doi:10.1590/S0102-37722009000200015

Martins, T. S. (2013). Imagem corporal: Estudo transversal em candidatos ao serviço militar em juiz de fora (Master's thesis). Retrieved from http://www.ufjf.br/labesc/ files/2010/06/Imagem-Corporal-.-Estudo-transversalem-candidatos-ao-servi\%C3\%A7o-militar-em-Juiz-deFora- $\%$ E2\%80\%93-MG.pdf

Miranda, V. P. N., Filgueiras, J. F., Neves, C. M., Teixeira, P. C., \& Ferreira, M. E. C. (2012). Insatisfação corporal em universitários de diferentes áreas de conhecimento. Jornal Brasileiro de Psiquiatria, 61(1), 25-32. doi:10.1590/S0047-20852012000100006

Peixoto, M. R. G., Benicio, M. H. A., \& Jardim, P. C. B. V. (2006). Validade do peso e da altura auto-referidos: O estudo de Goiânia. Revista de Saúde Pública, 40(6), 1065-1072. doi:10.1590/S0034-89102006000700015

Silva, R. A., Horta, B. L., Pontes, L. M., Faria, A. D., Souza, L. D. M., Cruzeiro, A. L. S., \& Pinheiro, R. T. (2007). Bem-estar psicológico e adolescência: Fatores associados. Cadernos de Saúde Pública, 23(5), 1113-1118. doi:10.1590/S0102-311X2007000500013
Souza, M. R. R., Oliveira, J. F., Nascimento, E. R., \& Carvalho, E. S. S. (2013). Droga de corpo! Imagens e representações do corpo feminino em revistas brasileiras. Revista Gaúcha de Enfermagem, 34(2), 62-69. doi:10.1590/S1983-14472013000200008

Tavares, M. C. G. C. F. (2003). Imagem corporal: Conceito e desenvolvimento. Barueri, SP: Manole.

Tavares, M. C. G. C. F., \& Campana, A. N. N. B. (2009). Avaliação da imagem corporal: Instrumentos e diretrizes para pesquisa. São Paulo, SP: Phorte.

Thompson, J. K., van den Berg, P., Roehrig, M., Guarda, A. S., \& Heinberg, L. J. (2004). The Sociocultural Attitudes Towards Appearance Scale-3 (SATAQ-3): Development and validation. International Journal of Eating Disorders, 35(3), 293-304. doi:10.1002/eat.10257

Tiggemann, M. (2002). Media influences on body image development. In T. F. Cash \& T. Pruzinsky (Eds.), Body image: A handbook of theory, research, and clinical practice (pp. 91-98). New York, NY: Guilford.

Tod, D., Edwards, C., \& Hall, G. (2013). Drive for leanness and health-related behavior within a social/ cultural perspective. Body Image, 10(4), 640-643. doi:10.1016/j.bodyim.2013.05.002

World Health Organization. (2013). Global database on Body Mass Index. Retrieved from http://www.who.int/ bmi/index.jsp?introPage=intro_3 www.who.int/bmi

Zanchetta, J., Jr. (2009). Educação para a mídia: Propostas europeias e realidade brasileira. Educação \& Sociedade, 30(109), 1103-1122. doi:10.1590/S0101-73302009000400009

Melissa Bittencourt Jaeger graduated in psychology from the Universidade Federal de Ciências da Saúde de Porto Alegre.

Sheila Gonçalves Câmara is an Adjunct Professor of the Universidade Federal de Ciências da Saúde de Porto Alegre.

Received: June 11, 2014

1st Revision: Nov. 14, 2014

Approved: Feb. 11, 2015

How to cite this article:

Jaeger, M. B., \& Câmara, S. G. (2015). Media and life dissatisfaction as predictors of body dissatisfaction. Paidéia (Ribeirão Preto), 25(61), 183-190. doi:10.1590/1982-43272561201506 